\title{
Ekonomik Büyüme ve Demokrasi Bağlamında Çevre Sorunlarına Bakıș Teori ve Uygulama
}

PInar ÇUHADAR Melike ATAY POLAT 


\title{
(C) Copyright 2021
}

Bu kitabın, basım, yayın ve satış hakları Akademisyen Kitabevi A.Ş.'ne aittir. Anılan kuruluşun izni alınmadan kitabın tümü ya da bölümleri mekanik, elektronik, fotokopi, manyetik kağıt ve/veya başka yöntemlerle çoğaltılamaz, basılamaz, dağıtılamaz. Tablo, şekil ve grafikler izin alnmadan, ticari amaçh kullanılamaz. Bu kitap T.C. Kültür Bakanlı̆̆ bandrolü ile satılmaktadır.

\section{ISBN}

978-625-74-09-49-0

\section{Kitap Adı}

Ekonomik Büyüme ve Demokrasi Bağlamında

Çevre Sorunlarına Bakış Teori ve Uygulama

\author{
Yazarlar \\ Pınar ÇUHADAR \\ ORCID iD: 0000-0001-6302-7735 \\ Melike ATAY POLAT \\ ORCID iD: 0000-0001-9507-5942
}

Yayın Koordinatörü

Yasin DİLMEN

Sayfa ve Kapak Tasarımı

Akademisyen Dizgi Ünitesi

Yayıncı Sertifika No

47518

Baskı ve Cilt

Vadi Matbaacılık

Bisac Code

BUS000000

DOI

$\mathrm{XXX}$

\section{GENEL DAĞITIM Akademisyen Kitabevi A.Ş.}

Halk Sokak 5 / A

Yenişehir / Ankara

Tel: o312 4311633

siparis@akademisyen.com 
Aramizdan çok erken ayrılsalarda

Sevgilerini her zaman hissettiğimiz,

Bizlere duydukları inançla her zaman iyi işler yapmamız için güç veren,

Emeklerine müteşşekir olduğumuz,

Babam Mehmet ÖZDEMIR'e

Annem ve Babam Sevim - Yaşar ATAY'a

Saygı ve özlemle... 



\section{İÇİNDEKİLER}

Önsöz ........................................................................ vii

\section{Bölüm}

Çevre ve Demokrasi: Temel Kavramlar

1.1. Çevre Sorunlarında Sanayi Devrimi ve

Kapitalizmin Rolü .................................................................... 2

1.1.1. Liberal Ekonomik ve Siyasal Kurumların

Çevre Sorunlarına Bakış1.................................................... 8

1.1.2. Çevre ve Demokrasi................................................ 14

1.1.2.1. Demokrasinin Genel Özellikleri ................... 17

1.1.2.2. Demokrasi Modelleri ve Çevre

Sorunlarının Çözümüne Katkıları............................... 19

1.1.2.3. Ekolojik Demokrasi-Çevresel

Demokrasi Ayrımı ………………………………...... 25

1.2. Çevresel Adalet Tartışmaları............................................ 34

1.3. Politik Ekoloji ................................................................... 38

1.4. Çevre İdeolojileri ........................................................... 40

\section{Bölüm}

Çevre Sorunlarının Ekonomik Boyutları ve

Demokrasi İle İlişkisi

2.1. Çevre, Ekonomik Faaliyet ve İktisat:

Uzlaşmaz Üçlü Mü?

2.2. Ekonomik Büyümenin Çevre Sorunlarına

Etkisi

2.3. Çevre Kirliliğinin Ekonomik Refaha Etkisini

Ölçmedeki Sorunlar

2.4. Demokrasi Ve Ekonomik Büyümenin Çevre

Kalitesine Etkisi 65 


\section{Bölüm}

Görgül Analiz ve Politika Önerileri.................................71

3.1. Görgül Çalışmalarla İlgili Literatür.............................. 71

3.1.1. Ekonomik Büyüme ve Çevre İlişkisini

Ele Alan Çalışmalar.

3.1.2. Ekonomik Büyüme ve Demokrasi

İlişkisini Ele Alan Çalışmalar. 75

3.1.3. Demokrasi ve Çevre İlişkisinini Ele Alan

Çalışmalar.

3.2. Yöntem

3.3. Veri Seti 86

3.4. Model

3.5. Bulgular 103

Sonuç ve Değerlendirme 115

Kaynakça 119

Ekler. 


\section{ÖNSÖZ}

Sanayi Devrimi, üretim tarzı ve üretim ilişkilerinde yarattığı etkiler ile dünya ekonomi ve siyaset tarihinde bir kırılma noktası olarak kabul edilmektedir. Çevre sorunları da bu durumdan bağımsız değildir. Nitekim çevre sorunlarına neden olan insan eylemleri, tarihin her döneminde mevcut olsa da çevresel tahribata neden olan üretim pratikleri Sanayi Devrimi ile birlikte hız kazanmıştır. Sanayi Devrimi ile birlikte gelen sanayi kapitalizmi evresi, krizler, savaş dönemleri, karşıt siyasi eylemlere rağmen kesintisiz varlık göstermiştir.

1950’lerden başlayan ve büyük hızlanma olarak adlandırılan süreç ise küresel refahın artışına katkı sunup aşırı yoksul sayısının toplam dünya nüfusundaki payının \%42'den \%10'a inmesine olanak tanımıştır. Fakat bu refah, kara çevrelerinin \%75’i ile deniz çevresinin \%40’ının tahribatı, biyolojik çeşitlilik kaybı, fosil yakıt kullanımı ve ormansızlaşma ile gelen sera gazı emisyonlarıyla iklim değişikliği, çevre kirliliğinden kaynaklı yüksek ölüm oranları, geniş coğrafi alanlarda ekosistem yıkımları gibi ağır bedeller sonucu elde edilmiştir. Bu rakamların da gösterdiği gibi çevre sorunları ile mücadele artık gecikmeyi kabul etmeyecek boyutlara ulaşmıştır. Son yarım yüzyıldır üç kat artıp 7.5 milyara ulaşan dünya nüfusunun 4 milyarı kentlerde yaşarken toplam gelir de 12 kat artış göstermiştir. Bu artış grafiği üzerine geliştirilen senaryolar, 2050'de 10 milyara ulaşmış bir nüfusla birlikte çevre üzerindeki baskının da artacağını tahmin etmektedir (AÇA, 2019). 
$\mathrm{Bu}$ sorunların tanımlanması ve çözülmesinde piyasa odaklı bir bakış açısı sergileyen iktisat bilimi, doğal kaynakların sürdürülebilirliğini de insan merkezli bir bakış açısı ile ele almaktadır. İktisatçılar ve çevre bilimciler (ekolojistler) arasındaki anlayış farklılığı kuşkusuz iktisatçıların büyüme olgusuna atfettiği değerden bağımsız değildir. Fakat son dönemlerde yapılan iktisadi araştırmalar, geleneksel anlayışların aksine büyüme ve kalkınma dinamiklerinde kurumsal yap1ların dolayısıyla ekonomik ve siyasi tercihleri şekillendiren kurallar bütününün önemini daha yüksek sesle dile getirmektedir. Bu bakış açısı, karmaşık ilişkilerin bir ürünü olan çevre sorunlarında büyümenin rolünün yanı sıra siyasal kurumsal yapıların özelliklerinin de ele alınması ihtiyacını beraberinde getirmektedir.

Çevre, büyüme ve demokrasi üzerine odaklanan bu çalışmada analizler, refah düzeyi, demokrasi deneyimleri ve bu deneyimlerin bölgesel nitelikleri de dikkate alınarak Avrupa Birliği (AB) ülkeleri, İsviçre ve Norveç üzerine odaklanmıştır. Avrupa'nın uzun vadeli çevre politikaları geliştirme konusunda oldukça istekli davranması, konu üzerine araştırma yapan bilim insanları için verimli bir çalışma sahası sunmaktadır. Avrupa Birliği'nin uzun dönemli çevre politikaları konusunda 2050 vizyonunu ortaya koyan Çevre Eylem Planı, Avrupa doğal sermayesini korumak ve muhafaza etmek ve ilerletmek, kaynak kullanımında verimli, yeşil ve rekabetçi bir düşük karbon ekonomisi olmak, $\mathrm{AB}$ vatandaşlarının sağlıklarını ve refahlarını çevresel bozulmalardan kaynaklı risklerden korumak şeklinde sıralanabilecek bir dizi hedef ortaya koymaktadır. Fakat $A B$ vizyonu bu sorunların üstesinden gelmenin yalnız fon artışları ile mümkün olmadığını, yerel, bölgesel, ulusal otoritelerin koordinasyonu, vatandaş katılımı ve bilgi taban- 
larının genişletilmesinin de zaruri olduğunu tespit etmektedir. Avrupa'da politikaların başarıya ulaşması için hedeflenen yaşam tarzı değişiklikleri paydaşların dönüşüm sürecine etkin katılımını sağlayacak vizyon ve yöntemlerle de ilişkilendirilmektedir. Bu bağlamda çevresel adaletin sağlanması ve çevre sorunlarından en çok etkilenen bölgelerin sübvanse edilmesi de diğer bir politika önceliğini oluşturmaktadır (AÇA, 2019). İşte bu açık tanımlanmış politikaların yanı sıra çevre ve demokrasi verilerinin erişilebilirliği bizi teorik çerçevesi ortaya konulan konuların sınanması için Avrupa ülkelerine yönlendirmiştir.

Bu çerçevede oluşturulan kitabın birinci bölümünde çevre sorunları, ekonomi ve demokrasi ilişkisini irdelemekte kullanılacak temel kavramlar tanıtılmaktadır. Konu ile ilgili kavramsal tartışmaların detaylandırılması, iktisat yazınında çoğunlukta dikkate alınmayan bir dizi çevresel ideolojiyi ve bu ideolojiler çervesinde yürütülen tartışmaları iktisatçların dikkatine sunmayı amaçlamaktadır. Kitabın ikinci bölümünde ise ekonomik faaliyetler, ekonomik büyüme, iktisat bilimi, çevre sorunları ve demokrasi ilişkisi üzerine yürütülen tartışmalara yer verilmiştir. Kitabın üçüncü bölümünde de seçilen Avrupa ülkeleri üzerinde uygulaması yapılan panel Vektör Otoregresif (VAR) analizi ve panel Görünürde İlişkisiz Regresyon (GİR) analizinin genel özellikleri, veri seti ve analiz bulgularına yer verilmiştir. Yapılan görgül analizden elde edilen bulgularla farklı demokrasi türleri, büyüme ve çevre kalitesi ilişkisinin açıklık kazandığını da söylemek mümkündür.

Çevre sorunlarının eriştiği boyut dikkate alındığında son dönemlerde akademik yazında konuya olan ilginin yüksek olduğu da açıktır. Bu kitabın temel hedefi çevre sorunları, ekonomik büyüme ve demokrasi arasındaki etkileşimi teo- 
rik ve görgül bir analiz çerçevesinde ele almakla birlikte çevre sorunlarında siyasal kurumsal yapının etkisini de daha görünür kılmaktır. Kuşkusuz disiplinler arası bir çalışma alanı olan çevre, ekonomik büyüme ve demokrasi ilişkisi kapsamı itibariyle birçok konuyu içerisinde barındırmaktadır. Bu bakımdan özünü kaçırmadan ama sığ bir yaklaşımdan da uzak durarak konuyu irdelemek kitabın yazılmasının diğer bir hareket noktasını oluşturmaktadır Fakat tüm bu çabalara rağmen, çalışmada eksik kalan veya gözden kaçan noktalar da olacaktır. Bu nedenle çalışma üzerine getirilecek tüm eleştiri ve katkıların da konunun ve kitabın gelişmesi için kıymetli görüldüğününde altı çizilmelidir.

Dr. Öğr. Üyesi Pınar ÇUHADAR Mardin Artuklu Üniversitesi
Doç. Dr. Melike ATAY POLAT Mardin Artuklu Üniversitesi 


\section{KAYNAKÇA}

1. ABDELLATIF, A. M. (2003). Good Governance and Its Relationship to Democracy and Economic Development. In Global Forum III On Fighting Corruption And Safeguarding Integrity, Seoul, 20, 31.

2. ABRIGO, M. R. \& LOVE, I. (2016). Estimation of Panel Vector Autoregression in Stata. The Stata Journal, 16(3), 778-804.

3. ACARAVCI, A., BOZKURT, C. \& ERDOĞAN, S. (2015). MENA Ülkelerinde Demokrasi-Ekonomik Büyüme İlişkisi. İşletme ve İktisat Çalışmaları Dergisi, 3(4), 119-129.

4. ACEMOGlU, D., NAIDU, S., RESTREPO, P. \& ROBINSON, J. A. (2019). Democracy Does Cause Growth. Journal of Political Economy, 127(1), 47-100.

5. AÇA (2019). Avrupa Çevre Durum Genel Görünüm Raporu 2020. Lüksemburg: Avrupa Birliği Yayınlar Dairesi Erişim: https://www.eea. europa.eu/tr/publications/avrupa-da-cevre-durum-ve-genel/download.

6. ADAMS, S. \& KLOBODU, E.K.M. (2017). Urbanization, Democracy, Bureaucratic Quality and Environmental Degradation. Journal of Policy Modeling, 39(6), 1-30.

7. ADAMS, S. \& ACHEAMPONG, A.O. (2019). Reducing Carbon Emissions: The Role of Renewable Energy and Democracy. Journal of Cleaner Production, 240, 1-13.

8. AGRAS, J. (1995). Environment and Development: An Economic Analysis of Pollution, Growth and Trade, Cornell University, Departmant of Agricultural, Resource and Managerial Economics, Master's Thesis, ABD.

9. AL-MUlAli, U., FEREIDOUNI, H. G., LEE, J. Y. \& BINTI CHE SAB, C. N. (2013). Examining the bi-directional Long Run Relationship between Renewable Energy Consumption and GDP Growth. Renewable and Sustainable Energy Reviews, 22, 209-222.

10. ALTINTAS, H. \& KASSOURI, Y. (2020). Is the Environmental Kuznets Curve in Europe Related to the Per-Capita Ecological Footprint or CO2 Emissions?. Ecological Indicators, 113, 1-14.

11. APERGIS, N. \& PAYNE J. E. (2014). Renewable Energy, Output, CO2 Emissions and Fossil Fuel Prices in Central America: Evidence from A Nonlinear Panel Smooth Transition Vector Error Correction Model. Energy Economics, 42, 226-232.

12. AKALIN, G.(ty). Kamu Ekonomisi. Akçağ Yayınları: Ankara

13. ARCIONI, E. \& MITCHELL, G. (2005). Environmental Justice in Australia: When the RATS Became IRATE, Environmental Politics, 14(3), 363-379, DOI: 10.1080/09644010500087590. 
14. ARUOBA, Ç. (1992). Çevre Ekonomisi, Gelişme Ekonomisi içinde İnsan Çevre Toplum (Editör: R. Keleş). İmge Kitabevi: Ankara

15. ASARA, V. (2015). Democracy Without Growth: The Political Ecology of the Indignados Movement. PhD Thesis, Universitat Autònoma de Barcelona, Ecological Economics and Environmental Management.

16. ASLAN, A., AlTinOZ, B. \& ATAY POLAT, M. (2020). The Nexus among Climate Change, Economic Growth, Foreign Direct Investments, and Financial Development: New Evidence From N-11 Countries. Environmental Progress \& Sustainable Energy, DOI: 10.1002/ ep.13585, 1-9.

17. BAKER, S. \& JEHLIČKA, P. (1998). Dilemmas of Transition: The Environment, Democracy and Economic Reform in East Central EuropeAn Introduction. Environmental Politics, 7(1), 1-26.

18. BANGURA, A. O. (2013). The Political Ecology of Sustainable Community Development in Sierra Leone. Doctoral Thesis, University of Exeter of Philosophy in Geography.

19. BARRO, R. J. (1996). Democracy and Growth. Journal of Economic Growth, 1, 1-27.

20. BAŞAR, S. \& TEMURLENK, M. S. (2007). Çevreye Uyarlanmış Kuznets Eğrisi: Türkiye Üzerine Bir Uygulama. Atatürk Üniversitesi İIBF Dergisi, 21(1), 1-12.

21. BÅTSTRAND, S. (2015). Climate Change: Challenging Democracies, Challenging Parties. Doctoral Thesis, University of Bergen of Philophiae.

22. BOZKURT, Y. (2015). Toplumsal Ekoloji içinde (Editörler: F.Kırışık ve Ö. Sezer) Siyasal Ekoloji (2. Baskı), Detay Yayıncılık: Ankara.

23. CHOU, C. L., ZHANG, H.W., WANG, Y.M. \& Yang, M.F. (2019). The Influence of Democracy on Emissions and Energy Efficiency in America: New Evidence from Quantile Regression Analysis. Energy \& Environment, $1-17$.

24. CORPORATE WATCH (2018). A'dan Z'ye Yeşil Kapitalizm. Yeni İnsan Yayınevi: İstanbul.

25. ÇETİN, B. O. (2005). Ekofeminizm: Kadın-Doğa İlişkisi ve Ataerkillik, Sosyoekonomi, Ocak-Haziran 2005-1.

26. ÇEPEL, N. (1992). Doğa, Çevre Ekoloji ve İnsanlığın Ekolojik Sorunları. Altın Kitapları: İstanbul.

27. ÇINAR, Y. (2018). Modernleşme ve Bağımlılık Teorisi Ekseninde Marshall Yardımı ve Türkiye. MCBÜ Sosyal Bilimler Dergisi, 16(2), 325-350.

28. ÇOBAN, A. (2002). Çevreciliğin İdeolojik Unsurlarının Eklemlenmesi. Ankara Üniversitesi SBF Dergisi, 57(3).

29. ÇOBAN, A. (2020). Çevre Politikası Ekolojik Sorunlar ve Kuram. İmge Kitabevi: Ankara 
30. ÇOBAN, M. N. (2019). Demokrasi ve Refah: AB Ülkeleri Üzerine Bir İnceleme. Gazi Kitabevi, 1. Baskı, Ankara.

31. DURU, B. (1995). Çevre Bilincinin Gelişim Sürecinde Türkiye’de Gönüllü Çevre Kuruluşları, AÜ Sosyal Bilimler Enstitüsü Yüksek Lisans Tezi, Ankara

32. DOWNEY, L. \& STRIFE, S. (2010). Inequality, Democracy, and the Environment. Organization and Environment, 23(2), 155-188.

33. DAĞDEMİR, Ö. (2003). Çevre Sorunlarına Ekonomik Yaklaşımlar ve Optimal Politika Arayışları. Gazi Kitabevi, 1. Baskı, Ankara.

34. DELLANNO, R. (2020). Reconciling Empirics on the Political Economy of the Resource Curse Hypothesis. Evidence from Long-Run Relationships between Resource Dependence, Democracy and Economic Growth in Iran. Resources Policy, 68, 1-13.

35. DINDA, S. (2004). Environmental Kuznets Curve Hypothesis: A Survey. Ecological Economics, 49, 431-455.

36. DOGAN, E. \& SEKER, F. (2016). Determinants of CO2 Emissions in the European Union: The Role of Renewable and Non-Renewable Energy. Renewable Energy, 94, 429-439.

37. DOWNEY, L. \& STRIFE, S. (2010). Inequality, Democracy, and The Environment. Organization and Environment, 23(2), 155-188.

38. DROSDOWSKI, T. (2006). On The Link Between Democracy and Environment, Diskussionsbeitrag, No. 355, Universität Hannover, Wirtschaftswissenschaftliche Fakultät, Hannover.

39. DRYZEK, J. S. (1992). Ecology and Discursive Democracy: Beyond Liberal Capitalism and the Administrative State. Capitalism Nature Socialism, 3(2), 18-42.

40. ECKERSLEY, R. (2020). Ecological Democracy and the Rise And Decline of Liberal Democracy: Looking Back, Looking Forward. Environmental Politics, 29(2), 214-234.

41. ENE, V. C. (2014). The Citizens' Public Participation under European Union Law and Environmental Law. The USV Annals of Economics and Public Administration, 14, 1(19), 231-237.

42. ERDOĞAN, S. (2020). Demokrasi ve Büyüme İlişkisi: Türkiye için Bir Analiz. Erciyes Üniversitesi İktisadi ve İdari Bilimler Fakültesi Dergisi, $56,161-178$.

43. ERGÜN, S. \& ATAY POLAT, M. (2015). OECD Ülkelerinde CO Emisyonu, Elektrik Tüketimi ve Büyüme İlişkisi. Erciyes Üniversitesi İİBF Dergisi, 45, 115-141.

44. ERIKSSON, C. \& PERSSON, J. (2003). Economic Growth, Inequality, Democratization and The Environment. Environmental and Resource Economics, 25, 1-16.

45. FARZANEGAN, M. R. \& MARKWARDT, G. (2018). Development and Pollution in the Middle East and North Africa: Democracy Matters. Journal of Policy Modelling, 40, 350-374. 
46. FARZIN, Y. H. \& BOND, C. A. (2006). Democracy and Environmental Quality. Journal of Development Economics, 81, 213-235.

47. FREDRIKSSON, P. G., SAUQUET, A. \& WOLLSCHEID, J. R. (2016). Democracy, Political Institutions, and Environmental Policy. Reference Module In Earth Systems And Environmental Sciencies.1-7, DOI: 10.1016/B978-0-12-409548-9.09714-1.

48. FREDRIKSSON, P. G., NEUMAYER, E., DAMANIA, R. \& GATES, S. (2005). Environmentalism, Democracy and Pollution Control. Journal of Environmental Economics and Management, 49, 343-365.

49. GELLERS, J. C. \& JEFFORDS, C. (2018). Toward Environmental Democracy? Procedural Environmental Rights and Environmental Justice. Global Environmental Politics, 18(1), 99-121.

50. GENGENBACH, C., PALM, F. C., \& URBAIN, J. P. (2009). Panel Unit Root Tests in the Presence of Cross-Sectional Dependencies: Comparison and Implications for Modelling. Econometric Reviews, 29(2), 111-145.

51. GREENMATCH (2018). The Most Eco-Costly Countries in the EU Which EU Country Is the Most Environmentally Unfriendly? Erişim: https://www.greenmatch.co.uk/blog/2018/07/top-eco-costly-countries-in-eu.

52. GROSSMAN, G. M. \& KREUGER, A. B. (1991), Environmental Impacts of a North American Free Trade Agreement. NBER Working Paper, No. 3914, İnternet Adresi: http://www.nber.org/papers/w3914.pdf, Erişim Tarihi: 24.05.2016.

53. GRUNDLER, K. \& KRIEGER, T. (2016). Democracy and growth: Evidence from a Machine Learning Indicator. European Journal of Political Economy, 45, 85-107.

54. GUPTE, M. \& BARTLETT, R. V. (2007). Necessary Preconditions for Deliberative Environmental Democracy? Challenging The Modernity Bias of Current Theory. MIT Press

55. HAN, J., DU, T., ZHANG, C. \& QIAN, X. (2018). Correlation Analysis Of CO2 Emissions, Material Stocks and Economic Growth Nexus: Evidence from Chinese Provinces. Journal of Cleaner Production, 180, 395-406.

56. HOLTZ-EAKIN, D. \& SELDEN, M.S. (1995). Stoking the Fires? CO2 Emissions and Economic Growth. Journal of Public Economics, 57, 85101.

57. HSIAO, C. (2003). Analysis of Panel Data (No. 54). Cambridge University Press.

58. HAYALOĞLU, P. (2015). MINT Ülkelerinde Demokrasi Ekonomik Büyümeyi Nasıl Etkilemektedir?. Uluslararası Ekonomi ve Yenilik Dergisi, 1(1), 17-29. 
59. HOUSER, N. O. (2009). Ecological Democracy: An Environmental Approach to Citizenship Education. Theory \& Research in Social Education, 37(2), 192-214.

60. HOOSEN, F. (2010). An Investigation into the Role of Public Participation in Achieving Social Justice: A Case Study of EIAs Undertaken (Under Old and New Regulations) in South Durban. Master Thesis, University of Witwatersrand, Braamfontein.

61. HUN, E. (1992). Canlı Çevrenin Dünü Bugünü ve Yarını içinde İnsan Çevre ve Toplum. (Editör: R. Keleş).İmge Kitabevi: Ankara.

62. HUNT, E. K. \& LAUTZENHEISER, M. (2019). İktisadi Düşünceler Tarihi: Eleştirel Bir Perspektif (2.Bask1). Siyasal Kitabevi: Ankara

63. IWIŃSKA, K., KAMPAS, A. \& LONGHURST, K. (2019). Interactions between Democracy and Environmental Quality: Toward a More Nuanced Understanding. Sustainability, 11, 1-17.

64. JEBLI, M. B. \& YOUSSEF, B. F. (2015).The Environmental Kuznets Curve, Economic Growth, Renewable and Non-Renewable Energy and Trade in Tunisia. Renewable and Sustainable Energy Reviews, 47, 173-185.

65. KASHWAN, P. (2017). Inequality, Democracy, and the Environment: A Cross-National Analysis. Ecological Economics, 131, 139-151.

66. KELEŞ, R. (1992). Çevre ve Siyaset içinde İnsan Çevre ve Toplum. (Editör: R. Keleş).İmge Kitabevi: Ankara

67. KELEŞ, R. \& Hamamc1, C.(1993). Çevrebilim. İmge Kitabevi:Ankara

68. KIRIŞIK, F. (2015). Ekolojik Sorunların Çözümünde Derin Ekoloji Yaklaşımı içinde (Editörler: F.Kırışık ve Ö. Sezer) Siyasal Ekoloji (2. Baskı), Detay Yayıncılık: Ankara

69. KIM, Y., KIM, S., BAEK, J. \& HEO, E. (2018). The Linkages between Democracy and the Environment: Evidence from Developed and Developing Countries. Energy \& Environment, 30(5), 1-12.

70. KITCHEN, L., MILBOURNE, P., MARSDEN, T., \& BISHOP, K. (2002). Forestry and Environmental Democracy: The Problematic Case of the South Wales Valleys. Journal of Environmental Policy and Planning, 4(2), 139-155.

71. KİRMANOĞLU, H. (2009). Kamu Ekonomisi Analizi (2. Baskı). Beta Yayınları İstanbul

72. KOB, R. A. (2000). Riding the Momentum of Smart Growth: The Promise of Eco-Development and Environmental Democracy. Tulane Environmental Law Journal, 14, 139-169.

73. KOÇAK, E. \& UZAY, N. (2017). Türkiye'de Demokrasi ve Ekonomik Büyüme İlişkisi: Ampirik Bir Araştırma. Yönetim ve Ekonomi, 24(3), 705-723. 
74. LAZĂR, D., MINEA, A. \& PURCEL, A-A. (2019). Pollution and Economic Growth: Evidence from Central and Eastern European Countries. Energy Economics, 81, 1121-1131.

75. LI, Q. (2006). Democracy and Environmental Degradation. International Studies Quarterly, 50, 935-956.

76. LECOMBER, R. (1983). İktisadi Büyüme ve Çevre Sorunları. MacMillan İktisat Serisi, Akbank Kültür Yayınları: İstanbul

77. LONGO, S., B. \& BAKER, J. (2014). The Economy Versus Environment: The Influence of Economic Ideology ABD Political Identity on Perceived Threat of Eco Catatsrophe. The Sociological Quarterly, 55(2), 341-365.

78. LOPEZ, L. \& WEBER, S. (2017). Testing for Granger Causality in Panel Data. The Stata Journal, 17(4), 972-984.

79. LOVE, I. \& ZICCHINO, L. (2006). Financial Development and Dynamic Investment Behavior: Evidence from Panel VAR. The Quarterly Review of Economics and Finance, 46(2), 190-210.

80. MACNAGHTEN, P. \& JACOBS, M. (1997). Public Identification with Sustainable Development: Investigating Cultural Barriers to Participation. Global Environmental Change, 7(1), 5-24.

81. MADSEN, J. B., RASCHKY, P. A. \& SKALI, A. (2015). Does Democracy Drive Income in the World, 1500-2000?. European Economic Review, 78, 175-195.

82. MARQUES, A. C., FUINHAS, J. A. \& TOMÁS, C. (2019). Energy Efficiency and Sustainable Growth in Industrial Sectors in European Union Countries: A Nonlinear ARDL Approach. Journal of Cleaner Production, 239, 1-12.

83. MEYERS, C. J. (1974). An Introduction to Environmental Thought: Some Sources And Some Criticisms. Ind. LJ, 50, 426.

84. MIDLASRKY, M. I. (1998). Democracy and the Environment: An Empirical Assessment. Journal of Peace Research, 35(3), 341-361.

85. MITCHELL, R. E. (2006). Green Politics or Environmental Blues? Analyzing Ecological Democracy. Public Understanding of Science, 15(4), 459-480.

86. MONGO, M., BELAID, F. \& RAMDANI, B. (2021). The Effects of Environmental Innovations on $\mathrm{CO} 2$ Emissions: Empirical Evidence from Europe. Environmental Science and Policy, 118, 1-9.

87. MUĆK, J. (2018). Econometrics of Panel Data. Retrieved from at:http://web.sgh.waw.pl/ jmuck/EoPD/Meeting1_2018.pd

88. MUŞ, M. (2017). Ekonomik Kalkınma ve Demokrasi İlişkisi. İşaret Yayınları: İstanbul.

89. NARAYAN, P. K. \& NARAYAN, S. (2010). Carbon Dioxide Emissions and Economic Growth: Panel Data Evidence from Developing Countries. Energy Policy, 38, 661-666. 
90. NARAYAN, P. K., NARAYAN, S. \& SMYTH, R. (2011). Does Democracy Facilitate Economic Growth or Does Economic Growth Facilitate Democracy? An Empirical Study of Sub-Saharan Africa. Economic Modelling, 28, 900-910.

91. NEVES, S. A., MARQUES, A. C. \& PATRICIO, M. (2020). Determinants of CO2 Emissions in European Union Countries: Does Environmental Regulation Reduce Environmental Pollution?. Economic Analysis and Policy, 68, 114-125.

92. NEWTON, J. L., FREYFOGLE, E. T. \& SUlliVAN, W. C. (2006). Land, Ecology and Democracy: A Twenty- First Century View. Politics and the Life Sciences, 25(1/2), 42-56.

93. NIU, S., DING, Y., NIU, Y., LI, Y., \& LUO, G. (2011). Economic Growth, Energy Conservation and Emissions Reduction: A Comparative Analysis Based on Panel Data for 8 Asian-Pacific Countries. Energy policy, 39(4), 2121-2131.

94. OBYDENKOVA, A. V. \& SALAHODJAEV, R. (2017). Climate Change Policies: The Role of Democracy and Social Cognitive Capital. Environmental Research, 157, 182-189.

95. OMAY, R. E. (2013). The Relationship Between Environment and Income: Regression Spline Approach. International Journal of Energy Economics and Policy, 3, 52.

96. OMRI, A., MABROUK, N. B. \& SASSI-TMAR, A. (2015). Modeling the Causal Linkages between Nuclear Energy, Renewable Energy and Economic Growth in Developed and Developing Countries. Renewable and Sustainable Energy Reviews, 42, 1012-1022.

97. OZTURK, I. \& ACARAVCI, A. (2010). CO2 Emissions, Energy Consumption and Economic Growth in Turkey. Renewable and Sustainable Energy Reviews, 14(9), 3220-3225.

98. ÖKMEN, M. (2004). Çevre ve Politika İçinde Çevre Sorunlarına Çağdaş Yaklaşımlar, Beta Yayını, İstanbul, ss.327-365.

99. PAROLA, G. (2013). Environmental Democracy: A Theoretical Construction. Environmental Democracy at the Global Level: Rights and Duties for a New Citizenship, 19-90.

100. PATA, U. K. (2018). Renewable Energy Consumption, Urbanization, Financial Development, Income and $\mathrm{CO}_{2}$ Emissions in Turkey: Testing EKC Hypothesis with Structural Breaks. Journal of Cleaner Production, 187, 770-779.

101. PESARAN, H. (2007). Simple Panel Unit Root Test in the Presence of Cross-Section Dependence. Journal of Applied Econometrics, 22, 265 312.

102. PETERS, M. A. (2017). Education for Ecological Democracy. Educational Philosophy and Theory, 49(10), 941-945, DOI: 10.1080/00131857.2017.1339408 
103. PETERSON, G. (2000). Political Ecology and Ecological Resilience: An Integration of Human and Ecological Dynamics. Journal of Ecological Economics, 35, 323-336

104. PICKERING, J. \& BÄCKSTRAND, S. D. (2020). Between Environmental and Ecological Democracy: Theory and Practice at the Democracy-Environment Nexus. Journal of Environmental Policy \& Planning, 22(1), 1-15.

105. POLICARDO, L. (2016). Is Democracy Good for the Environment? Quasi-Experimental Evidence from Regime Transitions. Environmental and Resource Economics, 64, 275-300.

106. RACHDI, H. \& SAIDI, H. (2015). Democracy and Economic Growth: Evidence in MENA Countries. Procedia-Social and Behavioral Sciences, 191, 616-621.

107. RAINER, H. (2013). The Political Ecology and Economy of Protected Areas and Violence: A Case Study of the Conflict of the Kivus in the Democratic Republic of Congo. The Doctoral Thesis, Departmant of Geography and Environment, The London School of Economics and Political Science.

108. RAMLOGAN, R. (2010). Using the Law to Achieve Environmental Democracy and Sustainable Development: An Elusive Dream for Trinidad and Tobago. Electronic Green Journal, 1(30), 1-14.

109. RADMEHR, R., HENNEBERRY, S. R. \& SHAYANMEHR, S. (2021). Renewable Energy Consumption, $\mathrm{CO} 2$ Emissions, and Economic Growth Nexus: A Simultaneity Spatial Modeling Analysis of EU Countries. Structural Change and Economic Dynamics, 57, 13-27.

110. SABOORI, B., SULAIMAN, J. \& MOHD, S. (2012). Economic Growth and CO2 Emissions in Malaysia: A Cointegration Analysis of the Environmental Kuznets Curve. Energy Policy, 51, 184-191

111. SALAHODJAEV, R. (2015). Democracy and Economic Growth: The Role of Intelligence in Cross-Country Regressions. Intelligence, 50, 228-234.

112. SARKODIA, S. A. \& ADAMS, S. (2018). Renewable Energy, Nuclear Energy and Environmental Pollution: Accounting for Political Institutional Quality in South Africa. Science of the Total Environment, 643, 1590-1601.

113. SAWARD, M. (1998). Green State/Democratic State, Contemporary Politics, 4(4), 345-356.

114. SCHLOSBERG, D. \& CARRUTHERS, D. (2010). Indigenous Struggles, Environmental Justice, and Community Capabilities. Global Environmental Politics, 10(4), 12-35.

115. SELDEN, T. M. \& SONG, D. (1994). Environmental Quality and Development: Is There a Kuznets Curve for Air Pollution Emissions?. Journal of Environmental Economics and Management, 27(2), 147-162. 
116. SEZER, S. (2015). Sosyalist Ekoloji: Gereklilik mi Ütopya mı? İçinde (Editörler: F.Kırışık ve Ö. Sezer) Siyasal Ekoloji (2. Baskı), Detay Yayıncilık: Ankara.

117. SHAFIK, N. \& BANDYOPADHYAY, S. (1992). Economic Growth and Environmental Quality: Time-Series and Cross-Country Evidence. World Bank Publications, 904.

118. SHAHBAZ, M., MUTASCU, M. \& AZIM, P. (2013). Environmental Kuznets Curve in Romania and the Role of Energy Consumption. Renewable and Sustainable Energy Reviews, 18, 165-173.

119. SHAHNAZI, R. \& SHABANI, Z. D. (2021). The Effects of Renewable Energy, Spatial Spillover of CO2 Emissions and Economic Freedom on CO2 Emissions in the EU. Renewable Energy, 169, 293-307.

120. SULAIMAN, C., ABDUL-RAHIM, A. S. \& OFOZOR, C. A. (2020). Does Wood Biomass Energy Use Reduce CO2 Emissions in European Union Member Countries? Evidence from 27 Members. Journal of Cleaner Production, 253, 1-7.

121. SURI, V. \& CHAPMAN, D. (1998). Economic Growth, Trade and Energy: Implications for the Environmental Kuznets Curve. Ecological Economics, 25(2), 195-208.

122. STERN, D. I. \& COMMON, M. S. (2001). Is There an Environmental Kuznets Curve for Sulfur?. Journal of Environmental Economics and Management, 41(2), 162-178.

123. STERN, D. I. (2003). The Environmental Kuznets Curve. International Society for Ecological Economics Internet Encyclopaedia of Ecological Economics, 1-18.

124. SÜMER, Ö, ALAK, A. \& TEKİN, A. (2020). Antropojen ve Antroposen Kavramlarının Tarihsel Gelişimine Yerbilimsel Bir Bakış. Türkiye Jeoloji Bülteni, 63 (1), 1-20.

125. ŞAHİN, D. (2017). Geçiş Ekonomilerinde Demokrasi ve Ekonomik Büyüme İlişkisi: Panel Veri Analizi. Anemon Muş Alparslan Üniversitesi Sosyal Bilimler Dergisi, 5(1), 45-57.

126. SZULECKI, K. (2017). Conceptualizing Energy Democracy. Environmental Politics, DOI: 10.1080/09644016.2017.1387294, 1-22.

127. TALBERTH, J. ( 2010). Measuring What Matters: GDP, Ecosystems and the Environment. Erişim: https://www.wri.org/blog/2010/04/measuring-what-matters-gdp-ecosystems-and-environment.

128. TEORELL, J., AKSEL S., HOLMBERG, S., ROTHSTEIN, B., ALVARADO PACHON, N. \& DALLI C., M. (2021). The Quality of Government Standard Dataset, version Jan21. University of Gothenburg: The Quality of Government Institute, http://www.qog.pol.gu.se doi:10.18157/ qogstdjan21 
129. TOTH, K. (2017). Public Participation, Sustainability and Environmental Awareness: Case Study of the Effect of Wisdom Councils on Participants in the Region Bregenzerwald. Master's Thesis, Univesity of Copenhagen Department of Food and Resource Economics, Vienna.

130. TURGUT, E. \& UÇAN, O. (2019). Yolsuzluğun Vergi Oranları ile Olan İlişkisinin OECD Ülkeleri Örnekleminde İncelenmesi. Niğde Ömer Halisdemir Üniversitesi Sosyal Bilimler Enstitüsü Dergisi, 1(3), 1-17.

131. TÜTÜNCÜ, A. (2020). Gelişmekte Olan Ülkelerde Demokrasinin Ekonomik Büyümeye Etkisi. Sosyoekonomi, 28(44), 27-40.

132. ULUĞ, E. (1992). Çevre Kirlenmesinin Boyutları içinde İnsan Çevre ve Toplum. (Editör: R. Keleş). İmge Kitabevi: Ankara

133. UNGARO, D. (2006). Ecological Democracy. International Review of Sociology, 15(2), 293-303.

134. UZAR, U. (2020). Political Economy of Renewable Energy: Does Institutional Quality Make a Difference in Renewable Energy Consumption?. Renewable Energy, 155, 591-603.

135. WALKER, P. A. (1999). Democracy and Environment: Congruencies and Contradictions in Southern Africa. Political Geography, 18, 257284.

136. WANG, N., ZHU, H., GUO, Y. \& PENG, C. (2018). The Heterogeneous Effect of Democracy, Political Globalization, and Urbanization on PM2.5 Concentrations in G20 Countries: Evidence from Panel Quantile Regression. Journal of Cleaner Production, 194, 54-68.

137. WATES, J. (2005). The Aarhus Convention: A Driving Force for Environmental Democracy. Journal for European Environmental \& Planning Law, 2(1), 2-11.

138. WILSON, H.(2006).Environmental Democracy and the Green State. Polity, 38(2), 276-294.

139. WONG, J. K. (2016). A Dilemma of Green Democracy. Political Studies, 64(1_suppl), 136-155.

140. WORLD COUNT (2021). Are We Destroying Our World? Erişim: https://www.theworldcounts.com/stories/environmental-degradation-facts.(10.05.2021)

141. VICTOR, P.A. (1978). İktisat ve Çevre Kirliliği. MacMillan İktisat Serisi, Akbank Kültür Yayınları: İstanbul

142. YOU, W.H., ZHU, H.M., YU, K. \& PENG, C. (2015). Democracy, Financial Openness and Global Carbon Dioxide Emissions: Heterogeneity across Existing Emission Levels. World Development, 66, 189-207. 